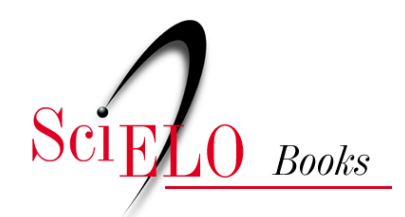

\title{
Posfácio \\ Entrevista com Don Ihde - vinte e sete anos de Tecnologia e o Mundo da Vida
}

\author{
Don Ihde \\ Maurício Fernando Bozatski (transl.)
}

BOZATSKI, M.F., transl. IHDE, D. Posfácio: Entrevista com Don Ihde - vinte e sete anos de Tecnologia e o Mundo da Vida. In: Tecnologia e o mundo da vida: do jardim à terra [online]. Chapecó: Editora UFFS, 2017, pp. 255-295. ISBN: 978-85-64905-61-0. https://doi.org/10.7476/9788564905610.0012.

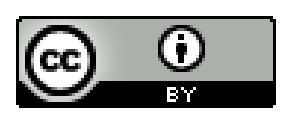

All the contents of this work, except where otherwise noted, is licensed under a Creative Commons Attribution 4.0 International license.

Todo o conteúdo deste trabalho, exceto quando houver ressalva, é publicado sob a licença Creative Commons Atribição 4.0.

Todo el contenido de esta obra, excepto donde se indique lo contrario, está bajo licencia de la licencia $\underline{\text { Creative Commons }}$ Reconocimento 4.0. 


\section{Posfácio: EnTrevista com Don IHDE - VINTE E SETE ANOS DE Tecnologia e o Mundo da Vida}

$1^{\circ}$ de março de 2017

\section{Entrevista com o filósofo Don Ihde sobre o livro Tecnologia e o Mundo da Vida}

Maurício Bozatski: Quando o livro foi lançado há 27 anos, você detalhou quatro relações básicas entre os humanos e a tecnologia: relações de incorporação, relações hermenêuticas, relações de alteridade e relações de segundo plano. Com a emergência de novas tecnologias no campo da medicina, robótica e o uso massivo em todo o mundo de outras, como os telefones celulares, você ainda acredita que estas quatro categorias conceituais de relações são o suficiente para descrever todas as relações humano-tecnologia?

Don Ihde: De fato quando eu estava escrevendo Tecnologia e o Mundo da Vida eu considerei uma quinta relação humano-tecnologia, a relação cibernética que seria relativa às tecnologias de implante. Mas estas eram raras na época e eu mesmo tinha poucos implantes naquela época (restaurações nos dentes, suturas). Agora, sendo um homem idoso, com vários implantes (estente, joelhos, anel de válvula cardíaca, restaurações e suturas) eu adicionaria uma quinta relação. Mas Peter-Paul Verbeek tem seguido nesta direção. 
MB: Quando você falou sobre o aspecto pluricultural das tecnologias, especialmente das tecnologias de imagem, é possível entender que alguns filósofos do século XX, em sua maioria da Escola de Frankfurt, reagiram contra as mídias de massas e contra a popularização da cultura que era promovida por revistas e pela televisão. Tais reações que enfatizam os aspectos negativos das tecnologias e são descritas em conceitos tais como "colonização do mundo da vida", etc., são o resultado de uma compreensão equivocada das relações humano-tecnologia ou são reações que visam manter a chamada alta cultura acessível apenas às elites?

DI: Eu sou bastante simpático a muito da tradição da Escola de Frankfurt e quase realizei meu doutorado com o próprio Marcuse, ele estava na época em Brandeis, mas logo depois se mudou para San Diego, mas considero, sim, que há muito de um elitismo germânico contido nestas teorias. Especialmente eu não gosto de Adorno, mas hoje em dia acho Andrew Feenberg bastante compatível.

MB: Algumas recomendações foram fornecidas sobre a forma como podemos tornar a ciência tecnológica mais amigável para o planeta e à humanidade, algumas destas recomendações foram sobre a necessidade de desmitificar e desmasculinizar a ciência tecnológica. Podemos dizer que algum progresso foi realizado nesta tarefa?

DI: Este é um dos principais tópicos atualmente e, sim, eu continuo pensando que o balanço nas questões de gênero e a desmitificação são necessários. Mas as divisões são diferentes do que eram. Atualmente a emergência de um tipo de robótica, Inteligência Artificial e automação parecem ameaçar a humanidade, enquanto eu considero que haja muito de um retorno ao cartesianismo que precisa de crítica. Humanos em colaboração com as tecnologias são muito mais positivos e pode haver inovações e melhores trajetórias para o desenvolvimento. Eu não gosto muito de pós ou trans-humanismo, no entanto.

MB: O complexo militar-industrial continua direcionando o desenvolvimento da ciência e da tecnologia? A situação das humanidades e das artes melhorou, continua a mesma ou ficou pior?

DI: Existe infelizmente muito antagonismo às artes e às humanidades por parte das dimensões tecnocráticas da tecnosciência e muitas organizações universitárias humanísticas encolheram ou foram transformadas - nem todas negativamente. Eu penso que os arranjos interdisciplinares são frequentemente bastante produtivos, mas as disciplinas clássicas são muito antiquadas mesmo. 
MB: Nestes 27 anos, a relação entre a ciência-tecnologia e o meio ambiente melhorou? Aquelas crianças educadas pelos canais "National Geographic" e "Discovery Channel" que aprenderam a ter mais compaixão por nossos vizinhos animais e que são os engenheiros e cientistas de hoje são mais cuidadosos com o meio ambiente ou estão buscando os mesmos mitos do passado?

DI: Sim, graças aos documentários e mídias mais sofisticadas, muito melhorou. Humanos estão agora mais próximos e mais simpáticos ao mundo animal, mas eu me preocupo com retrocessos promovidos por aqueles que desejam glorificar a caça e a exploração animal. A ciência claramente compreende as ameaças das mudanças ambientais; os políticos não.

MB: O livro foi escrito nos anos da recente dissolução da União Soviética. Daquele momento até hoje nós temos agora a China como uma nova grande força mundial que tem o poder de gerar grande impacto, bons ou ruins, à economia e ao meio ambiente. Como você analisa esta ascensão da China para o futuro da ciência e da tecnologia e quais serão os impactos para o Ocidente?

DI: Há uma necessidade para uma mudança de atenção para o Pacífico. Quatro dos meus livros estão agora traduzidos para o Mandarim e eu realizei três viagens para realizar seminário na China (mais algumas para o Japão e para a Coréia). Mas um profundo problema continua relacionado às diferenças subjacentes à cultura antiga que é muito diferente das euro-americanas. Eu estou envolvido com pesquisas sobre a robótica nos EUA e no Japão, e as direções subculturais são bastante diferentes.

MB: O novo fenômeno tecnológico das redes sociais ajuda a criar uma atitude pós-moderna em direção a um mundo mais pluricultural ou elas estão criando uma bolha com consequências perigosas para a democracia, etc.?

DI: Eu penso que eventos políticos recentes, que foram amplamente facilitados pelas mídias sociais, são uma indicação de que as visões utópicas sobre as redes sociais são superficiais e geralmente perigosas.

MB: No livro você analisa a administração Reagan em algumas questões acerca da defesa e do orçamento para a ciência e tecnologia. O que você espera deste novo Presidente, aparentemente conservador, em questões como a destinação orçamentária, cuidado com o meio ambiente e sociedade pós-moderna? 
DI: Eu só direi que eu temo passar meus últimos anos de vida vivendo sob e através deste tempo atrasado e autoritário. Nossa atual administração representa o oposto de tudo que eu prezo: multiculturalismo, ambientalismo, bem-estar social, direitos das mulheres e das minorias e muito mais. 